\title{
Innovative educational environment: technologies of creation
}

\author{
Mankus I., Nedbaievska L., Darmosiuk V., Parkhomenko 0. \\ V.O. Sukhomlynskyi Mykolaiv National University, Mykolaiv, Ukraine
}

Received: $12.03 .2020 \quad$ Accepted: 27.03 .2020

\begin{abstract}
The implementation of educational reforms in Ukraine requires the modernization of teacher training. The imbalance between the social demand for highly qualified pedagogical staff and the outdated teacher training system stimulates the development of innovative educational environments, which should ensure the formation of high-level professional competence of university students. The article describes the experience of modeling an innovative environment by means of a student-centered training and practice center, which performs educational activities based on competency and STEM approaches. The conceptual basis of the technology is the guiding principles of partnership pedagogy, STEM education, competency and transdisciplinary approaches, technologies of studentcentered teaching. The content component of the technology is modeling of natural science and mathematical education on the basis of current educational standards for institutions of higher and secondary education. The procedural component of the technology is the set of innovative forms and methods of educational activity that are integrated into long-term socio-scientific projects. Modeling of innovative educational environment by means of STEM and Art education provided an opportunity to introduce social and scientific projects satellites: children and youth experimentarium "Time Line", "Bank of Science", "Interesting Science in the City Streets" and others. The results of the work of the educational scientific laboratory are the development and implementation of innovative forms of educational activity in the system of training of future teachers. Innovative technology of transdisciplinary approach in education can be implemented by means of STEM platforms. The Center's Scientific and Methodological Laboratory investigates the process of introducing higher education technologies, develops a network of interactive playgrounds based on the STEM approach and approves innovative forms of educational activity. The Elements of the developed innovative scientific infrastructure were introduced at the Faculty of Mechanics and Mathematics of the V.O. Sukhomlynskyi Mykolayiv National University and in the educational institutions that are partners of the project. Key words: STEM - education, student-centered learning, STEM-platform.
\end{abstract}

\section{Інноваційне освітнє середовище: технології створення}

\author{
Манькусь І. В., Недбаєвська Л. С., Дармосюк В. М., Пархоменко О. Ю. \\ Миколаївський національний університет ім. В.О. Сухомлинського, Миколаїв, Україна
}

\begin{abstract}
Анотація. Реалізація освітніх реформ в Україні обумовлює необхідність модернізації професійної підготовки педагогічних працівників. Дисбаланс між суспільним запитом на висококваліфікованих педагогічних працівників та застарілою системою педагогічної освіти стимулює до створення інноваційних освітніх середовищ, які мають забезпечити формування високого рівня професійної компетентності здобувачів вищої освіти. В статті висвітлюється досвід моделювання інноваційного середовища засобами студентоцентрованого навчально-практичного центру, який здійснює освітню діяльність на основі компетентнісного та STEM - орієнтованого підходів. Концептуальною основою запропонованої технологї̈ $€$ провідні принципи педагогіки партнерства, STEM - освіти, компетентнісного та трансдисциплінарного підходів, технології особистісно-орієнтованого навчання. Змістовою складовою технології є моделювання природничоматематичної освіти на основі діючих освітніх стандартів в закладах вищої та середньої освіти. Процесуальною складовою технології $€$ сукупність інноваційних форм та методів освітньої діяльності, які інтегруються в довгострокові соціально-наукові проекти. Моделювання інноваційного освітнього середовища засобами STEM та Art освіти надало можливість запровадити соціально-наукові проекти супутники: дитячоюнацький експериментаріум «Лінія часу», «Bank of science», "Цікава наука на вулицях міста" та інші.
\end{abstract}

\footnotetext{
Corresponding Author: Darmosiuk Valentyna Mykolaivna, Tel. (0512)37-88-16 . E-mail: darmosiuk@gmail.com V.O. Sukhomlynskyi Mykolaiv National University

Nikolska Street, 24, Mykolaiv 54001, Ukraine

Відповідальний автор: Дармосюк Валентина Миколаївна, Тел. (0512)37-88-16 . E-mail: darmosiuk@gmail.com Миколаївський національний університет ім. В.О. Сухомлинського, вул. Нікольська, 24, м. Миколаїв, 54001
} 
Результатами роботи освітньо-наукової лабораторії є розробка та впровадження інноваційних форм освітньої діяльності в систему підготовки майбутніх вчителів. Інноваційна технологія трансдисциплінарного підходу в освітній діяльності може бути реалізована засобами STEM - майданчиків. Науково-методична лабораторія центру досліджує процес запровадження технологій вищої школи, розробляє мережу інтерактивних майданчиків на засадах STEM-орієнтованого підходу та здійснює апробацію інноваційних фрорм освітньої діяльності. Елементи розробленої інноваційної наукової інфраструктури запроваджені на механікоматематичному факультеті Миколаївського національного університету ім. В.О. Сухомлинського та в освітніх закладах, які є партнерами проекту.

Ключові слова: STEM - освіта, студентоцентроване навчання, STEM - майданчик.

\title{
Инновационная образовательная среда: технологии создания
}

\author{
Манькусь И. В., Недбаевская Л. С., Дармосюк В. Н., Пархоменко А. Ю. \\ Николаевский национальній университет им. В.А. Сухомлинского, Николаев, Украина
}

\begin{abstract}
Аннотация. Реализация образовательных реформ в Украине обусловливает необходимость модернизации профессиональной подготовки педагогов. Дисбаланс между общественным запросом на высококвалифицированных педагогов и устаревшей системой педагогического образования стимулирует к созданию инновационных образовательных сред, которые должны обеспечить формирование высокого уровня профессиональной компетентности соискателей высшего образования. В статье освещается опыт моделирования инновационной среды средствами студентоцентрованого учебно-практического центра, осуществляющего образовательную деятельность на основе компетентностного и STEM - ориентированного подходов. Концептуальной основой предложенной технологии являются ведущие принципы педагогики партнерства, STEM - образования, компетентностного и трансдисциплинарного подходов, технологии личностно-ориентированного обучения. Содержательной составляющей технологии является моделирование естественно-математического образования на основе действующих образовательных стандартов в учреждениях высшего и среднего образования. Процессуальной составляющей технологии является совокупность инновационных форм и методов образовательной деятельности, интегрируются в долгосрочные социально-научные проекты. Моделирование инновационной образовательной среды средствами STEM и Art образования позволило учредить социально-научные проекты спутники детскоюношеский Експериментариум «Линия времени», «Bank of science», "Интересная наука на улицах города" и другие. Результатами работы образовательно-научной лаборатории является разработка и внедрение инновационных форм образовательной деятельности в системе подготовки будущих учителей. Инновационная технология трансдисциплинарного подхода в образовательной деятельности может быть реализована средствами STEM - площадок. Научно-методическая лаборатория центра исследует процесс внедрения технологий высшей школы, разрабатывает сеть интерактивных площадок на основе STEMориентированного подхода и осуществляет апробацию инновационных форм образовательной деятельности. Элементы разработанной инновационной научной инфраструктуры введены на механико-математическом факультете Николаевского национального университета им. В.А. Сухомлинского и в образовательных учреждениях, которые являются партнерами проекта.
\end{abstract}

Ключевые слова: STEM - образование, студентоцентроване обучения, STEM - площадка.

\section{Bcmyn}

Задекларовані в Концепції розвитку НУШ зміни парадигми в освіті вимагають іншого підходу до розуміння та організації освітнього середовища. Новий зміст освіти вимагає також урізноманітнення технологій освітнього простору, зокрема, більш активного використання проектної, командної і групової діяльності. Адже саме вони утримують діалогічність, діяльнісно-творчий характер, простір для прийняття самостійних рішень, творчості і креативності.

Посилення розвитку науково-технічного напряму в навчально-методичній діяльності на всіх освітніх рівнях; створення науково-методичної бази для підвищення творчого потенціалу молоді та профресійної компетентності педагогічних працівників обумовлює необхідність використання інноваційних форм і методів освітньої діяльності.

Метою і змістом навчання у такому середовищі $є$ набуття учасниками особистісного досвіду: орієнтованого, діяльнісного, творчого, аксіологічного і відповідних компетенцій.

Формування такого досвіду буде проходити успішно за умови застосування технологій STEMосвіти та проектних технологій. Ці технології забезпечують комплексний міждисциплінарний підхід, який 
дозволяє створити таке освітнє середовище, в якому кожен стає активним учасником, а не пасивним спостерігачем у навчанні.

Формування компетентностей майбутнього викладача та пов'язані з цим дидактичні проблеми інновацій в освітній діяльності відображені у працях педагогів - вчених і практиків [1-11], в яких досліджуються нові максимально ефективні технології освітньої діяльності результатом впровадження яких є формування високо адаптованої творчої особистості. Наразі в європейських країнах збільшилась кількість досліджень з проблем конструювання освітнього середовища в контексті розвитку STEM освіти.

Зарубіжний досвід впровадження STEM - освіти досліджували О. В. Бутурліна, І.П. Василашко, О.А. Коваленко, О. В. Сапрунова, Н.В. Сороко, С.В. Федоренко. В їхніх роботах наведені успішні приклади впровадження STEM - освіти в різних країнах світу та реалізація цього напрямку в Україні.

Результати чисельних досліджень вчених методистів [12-15], свідчать, що запровадження в освітні середовища інноваційних технологій є передумовою переходу від знаннєво - просвітницької парадигми освіти до парадигми продуктивної діяльності, коли студенти засвоюють не готовий досвід досліджень у природничо-математичній галузі, а беруть активну участь у створенні власного освітнього продукту.

Мета роботи: висвітлення досвіду моделювання інноваційного освітнього середовища засобами STEM - освіти в рамках студентоцентрованого навчально-практичного центру.

\section{II Матеріал і методи дослідження}

Моделювання сучасного змісту освіти вимагає урізноманітнення технологій освітнього простору. Одним із компонентів організації освітньої діяльності $€$ створення при 3ВО студентоцентрованих навчально-практичних центрів, ідея яких полягає у створенні інноваційного освітнього середовища, яке являє собою розгалужену систему пошуку, розвитку, підтримки та супроводу обдарованої молоді на основі інновацій в методах і формах освітньої діяльності та поєднує змістову компоненту з технічною, математичною, художньою творчістю, використанням мультимедійних засобів навчання та фрізичним експериментом для формування навичок наукової діяльності, винахідництва та креативу майбутніх фрахівців [16-17].

Однією із значущих компонентів стратегії сучасної освіти стала орієнтація на активне навчання через організацію STEM-орієнтованого підходу, в якому акцент робиться на посилення уваги до вивчення фрізики, хімії, біології, інформатики, математики. Різні види STEM-майданчиків забезпечують поєднання змістової компоненти з технічною, математичною, художньою творчістю, формування навичок наукової діяльності, винахідництва, креативу, що відповідає основним засадам Концепції нової української школи [18-19]. Технології майстер-класу та проектної діяльності сприяють формуванню професійних компетентностей майбутніх викладачів природничо-математичних дисциплін [20-21].

Концептуальною основою створення інноваційного освітнього середовища $є$ Закон про вищу освіту (2014), Закон про освіту (2017), Концепція НУШ, всеукраїнський експеримент «Створення вітчизняної моделі авторської школи», Концепція педагогічної освіти (2018).

В процесі дослідження колектив лабораторії використовує низку методів, серед яких педагогічний експеримент, педагогічне прогнозування, абстрактно-логічний; графічний; методи аналізу та синтезу, аналогії, порівняння; математичне моделювання.

\section{III Результати}

Розробка та впровадження освітніх продуктів (саморобне фрізичне обладнання, діючі моделі механізмів, моделі фрізичних явищ, майстер-класи, міні-проекти та ін.) в різнорівневі освітні середовища привела до необхідності створення у навчально-практичному центрі освітньо-наукової лабораторії «Крок до науки». 
Реалізація ідеї щодо впровадження інноваційних форм і методів освітньої діяльності студентоцентрованого навчально практичного центру визначила необхідність створення науково-методичної лабораторії.

Науково-методична лабораторія технологічної підготовки викладача природничо-математичних дисциплін $€$ однією з наукових складових навчально-практичного центру. Колектив лабораторії досліджує проблеми осучаснення змісту і технологій природничо-математичної освіти.

Одним з елементів осучаснення змісту освіти $€$ галузь нанотехнологій. Перерахувати всі застосування нанотехнологій, практично неможливо. Назвемо тільки деякі з них:

- елементи наноелектроніки і нанофотоніки (напівпровідникові транзистори і лазери, фотодетектори, сонячні батареї, різні сенсори);

- обладнання надгустого запису інформації;

- телекомунікаційні, інформаційні і обчислювальні технології, суперкомп'ютери;

- відеотехніка - плоскі екрани, монітори, відео проектори;

- молекулярні електронні обладнання, в тому числі перемикачі і електронні схеми на молекулярному рівні;

- паливні елементи і обладнання збереження енергії;

- обладнання мікро- і наномеханіки, в тому числі молекулярні мотори і наномотори, нанороботи;

- авіаційні і космічні програми;

- обладнання контролю оточуючого середовища;

- цільова доставка ліків і протеїнів, біополімери і загоєння біологічних тканин, клінічна і медична діагностика, утворення штучних мускулів, кісток, імплантація живих органів;

- реєстрація і ідентифікація біологічно шкідливих агентів, безпека у сільському господарстві і при виробництві харчових продуктів.

Наприклад, при вивченні явищ поверхневого натягу рідин і змочування рідинами поверхні твердих тіл важливо не тільки розкрити фрізичні основи цих явищ, а й показати їх практичне застосування, особливо в нанотехнологіях, які $є$ новим етапом пізнання матерії. Деякі сучасні технології основані на результатах спостереження за живою природою і запозичення у неї унікальних принципів і ефектів. Одним із прикладів «співробітництва» людини з природою є так званий «ефект лотоса».

Елементом осучаснення змісту освіти $€$ ознайомлення освітнього середовища з останніми досягненнями сучасної фрізики, які відзначенні Нобелівською премією: світлодіоди, фрлуоресцентні мікроскопи, відкриття нейтрино, гравітаційні хвилі.

Колектив лабораторії $€$ організатором щорічних Міжнародних науково-практичних конференцій «Розвиток інноваційної діяльності в галузі технічних і фізико-математичних наук», на яких обговорюються проблеми удосконалення змісту освіти сучасними досягненнями природничоматематичних наук.

Розвиток суспільства в будь-якій країні залежить від системи освіти в ній. Пріоритетними завданнями освітньої програми НУШ $є$ організація навчання на основі компетентнісного підходу, що передбачає створення відповідного навчального середовища й відбору педагогічних технологій формування компетентностей учнів.

У всіх природничих науках і відповідних їм навчальних дисциплінах спільним предметом вивчення $€$ природа. Але кожна з цих наук вивчає лише окремі сторони, які властиві природі. При цьому кожний навчальний предмет пояснює і обґрунтовує окремі сторони Всесвіту і не може сформувати цілісну систему знань. Відтак, у навчальному процесі штучно розриваються на фізичні, хімічні, біологічні, історичні і т.ін. явища, які органічно пов'язані у природі. Тому використання провідного принципу STEMосвіти - трансдисциплінарного підходу дозволить здійснити модернізацію методологічних засад, змісту, обсягу навчального матеріалу предметів природничо-математичного та гуманітарного циклів, технологізацію процесу навчання та формування компетентностей якісно нового рівня, а саме інтегративних компетентностей у природничих науках і технологіях, соціальних і громадянських сферах, обізнаності та самовираженні у ссрері культури, екології і збереженні власного здоров'я.

Дуже важливим $є$ те, щоб до STEM- і Art-освіти отримали доступ учні маленьких та невеликих населених пунктів України - сіл, селищ та малих міст, оскільки, зазвичай, у них менше можливостей в отриманні якісної сучасної освіти. 
Інноваційна технологія трансдисциплінарного підходу в освітній діяльності може бути реалізована засобами STEM - майданчиків, які сприяють формуванню цілісного світогляду про історію виникнення, будову і розвиток оточуючого світу та розвитку інтелекту учнів.

Завдання майданчика:

- організація такого освітнього середовища, в якому б явища оточуючого світу отримували синхроністичне пояснення з точки зору фізики, біології, хімії, географії, математики, історії і за допомогою навіть творів художньої літератури, тобто STEM-майданчика;

- створення експозиції «Лінія часу», в якій відтворювати відомості про історію наукових відкриттів, вчених, історичні події різних періодів і т.ін. для формування умінь співвідносити події в історії природознавства, техніки, досягненнями в літературі та мистецтві; майданчика.

- підготовка матеріально-технічної бази для супроводу освітньої діяльності учасників

Кожна історична епоха пов'язана з видатними особистостями, які є творцями наук, тому історичні знання повинні поєднуватися із фактами, теоріями, законами, гіпотезами природничих наук. Таким чином, на нашу думку, найбільш повно буде реалізовано трансдисциплінарний підхід у освітній діяльності.

Наприклад, якщо розглядати, скажімо, історичний період 1810-1820 рр., то в хімії було створено таблицю атомних мас 45 хімічних елементів (Й. Берцеліус), у фізиці відкрито магнітну дію струму (Х. Ерстед), встановлені закони магнітної взаємодії (А. Ампер), в географії створені перші синоптичні карти (Г. Брандес) та відкрито Антарктиду (Ф. Беллінсгаузен і М. Лазарєв), у світовій літературі всі захоплюються творами Д. Байрона (Дон Жуан). А якщо готуємо матеріал періоду 1860-1865 рр., то мова йтиме про створення головної теорії електромагнітного поля Дж. Максвеллом (фізика), відкриття законів спадковості Г. Менделем (біологія), створення теорії О. Бутлеровим «Про хімічну будову речовини» (хімія), про скасування кріпацтва в Росії та рабства в США (історія, географрія); а в літературі відбулися дві події: у 1861 р. помер Т.Г. Шевченко, а у 1862 р. П.Чубинський написав вірша «Ще не вмерла Україна».

Сучасний світ характеризується зміною пріоритетів і соціальних цінностей: науково-технічний прогрес усвідомлюється як засіб розвитку духовно-багатої особистості. На перший план виходить людський фактор. Дійсно, людина стає мірою всіх речей і XXI ст. буде століттям наук про людину і людство.

Необхідність пізнання світу обумовлює розвиток особистості, гармонізації її з природою, іншими людьми, суспільством, державою.

Одна із головних причин відриву навчання від життя полягає в тому, що не приділяється достатньої уваги людській чуттєвій (емоційній) діяльності, тому однією із ключових компетентностей Нової української школи виділена загальнокультурна грамотність.

Хтось із видатних сказав: «Нещастя фрізики полягає в тому, що їі фундамент ніяк не досягне дна абсолютної істини». Та щастя її в тому, що час від часу народжуються великі світу цього, ті, хто присвячує своє життя справі, яка переживає їх на століття і тисячоліття.

Створення освітнього середовища, в якому учні познайомляться з фізичними істинами, як узагальненими результатами суспільно-історичної практики людства яка $€$ органічною складовою культури є метою STEM-майданчика «Bank of Science», в якому учні працюють над відтворенням соціального досвіду, наслідуванням його, а від так, набувають загальнокультурної грамотності.

Завдання майданчика:

- розробка майстер класу, який буде сприяти розвитку загальнокультурної і предметної компетентностей які є запорукою успішної реалізації учня як особистості й кваліфікованого працівника в сучасному суспільстві;

- забезпечення лабораторно-практичної бази для відтворення спостереження, пояснення 3 точки зору природничо-математичних наук відкриттів, зроблених у фізиці великими вченими.

Для його проведення використовують методику ознайомлення із грошовими знаками декількох держав на яких відображено своєрідність кожної країни - особливості її природи, культури, господарства, видатних діячів науки і техніки які прославили свою державу в світі і зробили неоціненний внесок у розвиток цивілізації. 
На першій купюрі, зокрема, зображений портрет А. Вольта (10000 лір). Потрапив він туди завдяки тому, що сконструював першу електричну батарею - Вольтів стовп, завдяки чому здобув прихильність самого Наполеона та титул графа..Для демонстрації цього ефекту необхідно взяти дві пластини із різних металів, приєднати до них низьковольтну лампочку і опустити пластини в солону воду. При цьому лампочка починає світитися. Згодом Вольта винайшов електричну батарею. Можна продемонструвати батарею, взявши декілька лимонів, оцинковані шурупи та мідний дріт. Встромивши ці електроди в кожну половинку лимона і з'єднавши їх послідовно, сполучаємо крайні лимони з світлодіодною лампочкою червоного кольору яка при цьому світиться.

А.Вольта вперше продемонстрував дослід зі статичною електрикою (електризація за допомогою удару). Цей дослід досить легко можна продемонструвати взявши одну пластину від розбірного конденсатора та пластину із оргскла а також електрометр. Зробивши 10-15 ударів металевою платиною по пластику помічаємо, що пластик зарядився.

А.Вольта $є$ яскравим прикладом того, як жага до пізнання робить великий ривок у розвитку людства і якби не він, наш світ не був би зараз таким, яким ми звикли його бачити.

На наступній купюрі зображено портрет Бенджаміна Франкліна (100 доларів), який довів електричну природу блискавки, запропонував у 1752-му році проект «Блискавковідводу», вперше застосував електричну іскру для вибуху пороху, встановив наявність «електричного вітру» з допомогою колеса, яке назване його ім'ям (Колесо Франкліна).

Як учений він був помітною фігурою в історії фізики, зробивши відкриття в галузі електрики. Б. Франклін - єдиний з батьків-засновників, хто скріпив своїм підписом три найважливіші історичні документи, що лежать в основі утворення Сполучених Штатів Америки: Декларацію Незалежності США, Конституцію США і Версальский мирний договір 1783 року, що формально завершив війну за незалежність 13-ти британських колоній в Північній Америці від Великої Британії, він був перший хто боровся проти рабства. За всі ці досягнення він потрапив на 100 доларову купюру.

Знайомимо з купюрою у 20 фунтів, на якій зображено портрет М. Фарадея. Заслуга цього вченого в тому, що він через відкриття явища електромагнітної індукції показав взаємозв'язок електричного і магнітного полів. Демонструють класичні досліди Фарадея по виявленню індукційного струму, показують використання цього явища в індукційних печах, магнітну левітацію за допомогою котушки Томсона, модель електричного генератора з допомогою магнітоелектричної машини. Таким чином, узагальнення результатів експериментів Фарадея дало змогу Максвеллу створити теорію електромагнітного поля.

На купюрі в 500 фрранків бачимо портрет Блеза Паскаля - французького філософа, письменника, фізика та математика. Він $€$ одним із засновників математичного аналізу, теорії ймовірностей, автором основного закону гідростатики. Відомий також винаходом гідравлічного преса й шприця. На честь Паскаля названа одиниця вимірювання тиску а також популярна мова програмування .Він проводив серії дослідів, результати яких виклав у «Трактаті про звуки», «Трактаті про рівновагу рідин», «Нові досліди, що стосуються порожнечі». Розповідь про цього вченого супроводжують дослідами зі шприцем, який використовують в медицині, техніці й кулінарії для введення рідин і газів під дією тиску поршня, демонстрацією картезіанського водолазу, явища гідростатичного парадоксу, гідравлічного пресу.

«Він перевершив розумом рід людський» - це слова про І. Ньютона, портрет якого на купюрі в 1 фунт стерлінгів. Ісаак Ньютон - англійський фрізик і математик, творець теоретичних основ механіки й астрономії. Він відкрив закон всесвітнього тяжіння, винайшов дзеркальний телескоп і був автором найважливіших експериментальних робіт з оптики. Його по праву вважають творцем класичної фрізики. Демонструють досліди, що пояснюють припливи і відливи морів та океанів, дисперсію світла та складання кольорів, закони руху, «не ньютонівську рідину», приплюснутість форми Землі.

Праці Ньютона одержали високу оцінку і за межами Англії - він був обраний іноземним членом Паризької академії наук.

На купюрі Сербії у 100 дінарів розміщено портрет Ніколи Тесли. Тесла ніколи не робив записів, не користувався математичними операціями. Він розумів суть речей, їх принципи, наприклад, світіння лампи денного світла біля високовольтного джерела напруги (трансформатора Тесла). За допомогою цього трансформатора демонструють цікаві і різноманітні ефекти, що виникають під час його роботи: стримери, тобто видима іонізація повітря, спарки - іскрові розряди, коронний розряд та дуговий. Тесла 
заклав підвалини для передачі енергії на великі відстані, безпровідного зв'язку і можливості користування такою енергією сьогодні.

\section{IV Обговорення}

На засадах трансдисциплінарного підходу в рамках STEM- та Art-технології створено та забезпечено функціонування дитячо-юнацького експериментаріуму в Явкинській школі Баштанської ОТГ Миколаївської області, який працює щодня і який вже відвідали декілька сотень учнів сільських шкіл об єднаної громади. Для забезпечення його роботи залучено викладачів декількох предметів, зусилля яких спрямовуються на з'ясування стану розвитку відповідної науки (предмету) в той чи інший час відповідної історичної доби. Встановлення самих таких горизонтальних часово-просторових зв'язків дозволяє повніше розкрити динаміку змін у світі науки, техніки, культури всесвітньої історії а, відтак, повніше розкрити національну, соціокультурну та загальнокультурну складову змісту освіти.

Результати виконання наукових досліджень представлені викладачами кафедри фрізики Миколаївського національного університету ім. В.О. Сухомлинського у навчальних посібниках «Сучасний урок фізики у контексті STEM-освіти» (2018), «Сучасна фізика в школі» (2016), «Сучасні досягнення фізики: матеріали до уроку» (2016), «Диференціальні рівняння» (2017), «Інноваційне освітнє середовище: технології створення» (2019).

Результати досліджень обговорюються на постійно діючому міжвузівському семінарі «Питання удосконалення змісту і методики викладання природничо-математичних дисциплін в середній і вищій школі». Кафедра видає щорічний науково-методичний журнал, який має державну реєстрацію Міністерства юстиції України від 24.11.2016р. № 3348/5.

\section{V Висновки}

Розробляючи зміст STEM- та Аrt-майданчиків, можна послуговуватись технологією трансдисциплінарного підходу для створення як освітніх так і соціальних проектів, в яких би обгрунтовувалися історичні події, передумови відкриттів, внесок окремих осіб у розвиток галузі та відбувалась мотивація до пошуку нової цікавої інформації.

STEM-майданчик «Bank of science» допоможе кожному учаснику набути цінностей і смислів життя, підтримати індивідуальність і творчу самобутність у сучасному глобалізованому світі. А свідоме прийняття молоддю загальнолюдських цінностей та гуманістичного ставлення до природи й трансформація їх у стратегічні орієнтири власної життєдіяльності $€$ найголовнішими результатами формування загальнокультурної грамотності.

Реалізація STEM - орієнтованого підходу до моделювання інноваційного освітнього середовища забезпечила ефективне впровадження трансдисциплінарного підходу в освітній діяльності та модернізацію технологій неформальної освіти.

\section{Бібліографрічні посилання}

1. Андрущенко В. П., Бондар В. І.. Модернізація педагогічної освіти відповідно до викликів XXI століття. Науковий вісник Миколаївського державного університету імені В. О. Сухомлинського. Серія: Педагогічні науки. 2010. Випуск 1.28. C. $12-20$.

2. Бібік Н.М. Переваги і ризики запровадження компетентнісного підходу в шкільній освіті. Український педагогічний журнал. 2015, № 1. С. 47-58.

3. Ватякіна Н. STEM-освіта: етапи становлення в Україні. Інформ. зб. для директора шк. та завід. дит. сад., 2015. № 17 - 18 (41). С. 47 - 52.

4. Дичківська І. М. Інноваційні педагогічні технології : навч. посібник. К. : Академвидав, 2004. 352 с.

5. Авшенюк Н.М., Десятов Т.М., Дяченко Л.М., Постригач Н.О., Пуховська Л.П., Сулима О.В. Компетентнісний підхід до підготовки педагогів у зарубіжних країнах: теорія та практика: монографія. Кіровоград: Імекс-ЛТД, 2014. 280 с.

6. Компетентнісний підхід у сучасній освіті: світовий досвід та українські перспективи: Бібліотека з освітньої політики ; під заг.ред. О.В. Овчарук. К.: «К.І.С.», 2004. 112 с.

7. Побірченко Н. С. Компетентнісний підхід у вищій школі: теоретичний аспект. Освіта та педагогічна наука. 2012. № 3 (152). C. 24-31.

8. Тараненко І. Розвиток життєвої компетентності та соціальної інтеграції. Кроки до компетентності та інтеграції в суспільство. К.: Контекст., 2000. С. 37-40 
9. Х Хоружа Л. Л. Компетентнісний підхід в освіті: ретроспективний погляд на розвиток ідеї. Педагогічна освіта : теорія $i$ практика : збірник наукових праць. К. : КМПУ імені Б.Д. Грінченка. 2007. № 7. (Серія "Психологія. Педагогіка"). 202 с.

10. Сисоєва С. Особистісно зорієнтовані технології: метод проектів : підручник для директора. К.: Плеяди, 2005. №910. C. 25-28.

11. Сисоєва С.О., Соколова І.В. Теорія і практика вищої освіти: навч.посіб. Київ-Маріуполь. 2016. 338 с.

12. Величко С. П., Сірик Е.П. Основні аспекти створення концептуальної моделі діяльності викладача фізики у підготовці фахівців нефізичного профілю. Збірник наукових праць Кам'янець-Подільського національного університету ім. Івана Огієнка. Серія : Педагогічна. 2017. Випуск 23. С. 125-129.

13. Іваницький О. І. Формування інтегральної компетентності майбутнього вчителя фрізики на засадах акмеологічного, контекстного та компетентністного підходів. Збірник наукових праць Кам'янець-Подільського національного університету ім. Івана Огієнка. Серія : Педагогічна. 2017. Вип. 23. С. 129-132.

14. Садовий М.І., Слюсаренко В.В., Трифонова О.М., Хомутенко М.В. Формування експериментально-орієнтованого навчального середовища вивчення фрізики. Science and Education a New Dimension. Pedagogy and Psychology, II(16), Issue: 33, 2014.-P. 79-84. URL: http://seanewdim.com /uploads/3/4/5/1/34511564/sadovyi_.._ slyusarenko_v.v._ trifonova_o.m._khomutenko_.v._the_formation_of_experimentally-oriented_learning_environment_in_studying_physics.pdf .

15. Шарко В.Д. Підготовка вчителів до компетентнісного орієнтованого навчання: технологічний аспект. Сборник научных трудов SWorld [научный журнал]. Одесса, 2015. С. 57-62.

16. Манькусь І.В., Дармосюк В.М., Васильєва Л.Я Інноваційне освітнє середовище як фактор підвищення якості вищої освіти. Інженерні та освітні технології, 2019. Т 7. №3. C. 40-49. DOI 10.30929/2307-9770.2019.07.03.04

17. Манькусь І.В., Недбаєвська Л.С., Дінжос Р.В. Підготовка фахівців в ЗВО: інновації в методах і формах. Науковий вісник Миколаївського національного університету імені В.О. Сухомлинського. Педагогічні науки. 2018. №3 (62), Том 2. С. $199-205$.

18. Дінжос Р.В., Недбаєвська Л.С., Манькусь І.В. STEM-майданчики як компонент розвитку нової української школи. Питання удосконалення змісту і методики викладання природничо-математичних дисциплін у середній $і$ вищій школі, 2018. №24. С. 5-7.

19. Манькусь І.В., Недбаєвська Л.С., Дармосюк В.М. Впровадження STEM-майданчиків як сучасних освітніх середовищ у професійній діяльності вчителя. Фізико-математична освіта, 2019. Випуск 1(19). С. 130-134. DOI 10.31110/24131571-2019-019-1-020.

20. Манькусь І.В., Недбаєвська Л.С. Технологія майстер-класу джерело формування професійних компетентностей викладача. Витоки педагогічної майстерності, 2017. №1. С. 229-233.

21. Недбаєвська Л. С., Манькусь І.В., Дінжос Р.В. Сучасний урок фрізики в контексті STEM-освіти. Миколаїв: МНУ, 2017. $93 \mathrm{c.}$

\section{References}

1. Andrushenko, V. P. (2010) Modernizatsiia pedahohichnoi osvity vidpovidno do vyklykiv XXI stolittia// Scientific Bulletin of Mykolaiv State University Sukhomlinsky. Series pedagogical sciences, Mykolaiv, Iss 1.28, npp. 12-20. [in Ukrainian]

2. Bibik, N.M. (2015) Perevahy i ryzyky zaprovadzhennia kompetentnisnoho pidkhodu v shkilnii osvit, Kyiv, № 1. pp. 47-58. [in Ukrainian].

3. Vatiakina, N. (2015). STEM-osvita: etapy` stanovlennya v Ukrayini [STEM-education: stages of formation in Ukraine]. Inform. zb. dlya dy'rektora shk. ta zavid. dy't. sad. - Information compilation for the school principal and head of the kindergarten, 17 - 18 (41), 47-52 [in Ukraine].

4. Dychkivska, I. M. Innovatsiini pedahohichni tekhnolohii, Kyiv, Akademvydav, 352 p. [in Ukrainian].

5. Avsheniuk N.M., Desiatov T.M., Diachenko L.M., Postryhach N.O., Pukhovska L.P., Sulyma O.V. (2014) Kompetentnisnyi pidkhid do pidhotovky pedahohiv u zarubizhnykh krainakh: teoriia ta praktyka. Kirovohrad. Imeks-LTD, 280 p. [in Ukraine].

6. Ovcharuk, O.V. et all (2004) Kompetentnisnyi pidkhid u suchasnii osviti: svitovyi dosvid ta ukrainski perspektyvy: Biblioteka z osvitnoi polityky. Kyiv.: «K.I.S.», 112 p. [in Ukrainian].

7. Pobirchenko, N. S. (2012) Kompetentnisnyi pidkhid u vyshchii shkoli: teoretychnyi aspekt// Osvita ta pedahohichna nauka. 2012. № 3 (152). npp. 24-31. [in Ukrainian].

8. Taranenko, I. (2000) Rozvytok zhyttievoi kompetentnosti ta sotsialnoi intehratsii// Kroky do kompetentnosti ta intehratsii v suspilstvo. K.: Kontekst., npp. 37-40. [in Ukrainian].

9. Khoruzha, L. L. (2007) Kompetentnisnyi pidkhid v osviti: retrospektyvnyi pohliad na rozvytok idei. Pedahohichna osvita : teoriia i praktyka : zbirnyk naukovykh prats. Kyiv.: KMPU imeni B.D. Hrinchenka. № 7. (Seriia "Psykholohiia. Pedahohika"). 202 p. [in Ukrainian]

10. Sysoieva, S. (2005) Osobystisno zoriientovani tekhnolohii: metod proektiv //Pidruchnyk dlia dyrektora. Kyiv: Pleiady, №9-10. npp. 25-28. [in Ukrainian].

11. Sysoieva S.O., Sokolova I.V. (2016) Teoriia i praktyka vyshchoi osvity: navch.posib. Kyiv-Mariupol. 2016.338 p. [in Ukrainian].

12. Velychko S. P., Siryk E.P. (2017) Osnovni aspekty stvorennia kontseptualnoi modeli diialnosti vykladacha fizyky u pidhotovtsi fakhivtsiv nefizychnoho profiliu// Zbirnyk naukovykh prats Kamianets-Podilskoho natsionalnoho universytetu im. Ivana Ohiienka. Seriia : Pedahohichna. Iss. 23. npp. 125-129. [in Ukraine]. 
13. Ivanytskyi, O. I. (2017) Formuvannia intehralnoi kompetentnosti maibutnoho vchytelia fizyky na zasadakh akmeolohichnoho, kontekstnoho ta kompetentnistnoho pidkhodiv// Zbirnyk naukovykh prats Kamianets-Podilskoho natsionalnoho universytetu im. Ivana Ohiienka. Seriia : Pedahohichna. Iss. 23. npp. 129-132. [in Ukraine].

14. Sadovyi M.I., Sliusarenko V.V., Tryfonova O.M., Khomutenko M.V. (2014) Formuvannia eksperymentalno-oriientovanoho navchalnoho seredovyshcha vyvchennia fizyky// Science and Education a New Dimension. Pedagogy and Psychology, II(16), Issue: 33.-npp. 79-84. [in Ukraine].

15. Sharko V. D. (2015) Pidhotovka vchyteliv do kompetentnisnoho oriientovanoho navchannia: tekhnolohichnyi aspekt // Sbornyk nauchnыkh trudov SWorld.. Odessa. npp. 57-62. [in Ukraine].

16. Mankus, I., Darmosiuk, V., Vasylieva, L. (2019). Innovative educational environment as a factor in improving the quality of higher education. Engineering and Educational Technologies, 7 (3), 40-49. doi: https://doi.org/10.30929/23079770.2019.07.03.04 [in Ukraine]

17. Mankus I.V., Nedbaievska L.S., Dinzhos R.V. (2018) Pidhotovka fakhivtsiv v ZVO: innovatsii v metodakh i formakh./Naukovyi visnyk Mykolaivskoho natsionalnoho universytetu imeni V.O. Sukhomlynskoho. Pedahohichni nauky. Mykolaiv., 2018. №3 (62), Tom 2. npp. 199-205. [in Ukraine].

18. Dinzhos, R.V., Nedbaievska, L.S., Mankus, I.V. (2018). STEM-majdanchy`ky` yak komponent rozvy'tku novoyi ukrayins'koyi shkoly' [STEM platforms as a component of the development of a new Ukrainian school]. Py tannya udoskonalennya

19. zmistu i metody'ky' vy'kladannya pry'rodny'cho-matematy'chny'x dy'scy'plin u serednij i vy'shhij shkoli - Issues of improving the content and teaching methods of natural and mathematical disciplines in secondary and high school, 24, 5-7 [in Ukraine].

20. Mankus I.V., Nedbaievska L.S., Darmosiyk V.M. (2019) Vprovadzhennia STEM-maidanchykiv yak suchasnykh osvitnikh seredovyshch u profesiinii diialnosti vchytelia. Fizyko-matematychna osvita. Iss 1(19). npp. 130-134. DOI 10.31110/24131571-2019-019-1-020. [in Ukraine].

21. Mankus, I.V., Nedbaievska, L.S. (2017). Texnologiya majster-klasu dzherelo formuvannya profesijny'x kompetentnostej vy kladacha [The technology of the master class is the source of the formation of the professional competence of the teacher]. Vy'toky' pedagogichnoyi majsternosti - The sources of pedagogical skills, 1, 229-233 [in Ukraine].

22. Mankus, I.V. \& Nedbaievska, L.S. \& Dinzhos, R.V. (2017). Suchasny’j urok fizy`ky` v konteksti STEM-osvity`: navchal’ny”j posibny'k [A modern physics lesson in the context of STEM education]. Mykolayiv [in Ukraine].

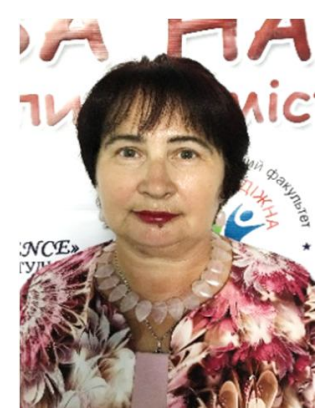

Манькусь Ірина Володимирівна,

Кандидат педагогічних наук, доцент, доцент кафедри фізики,

Миколаївський національний університет ім. В.О. Сухомлинського,

вул. Нікольська, 24, м. Миколаїв, Україна, 54001.

Тел. (0512)37-88-16 . E-mail: molodwave@gmail.com

\section{Mankus Iryna Volodymyrivna,}

Candidate of Pedagogical Sciences, Associate Professor, Associate Professor of Department of Physics,

V.O. Sukhomlynskyi Mykolaiv National University.

Nikolska Street, 24, Mykolaiv 54001, Ukraine

Tel. (0512)37-88-16 . E-mail: molodwave@gmail.com

ORCID: 0000-0001-6118-4614

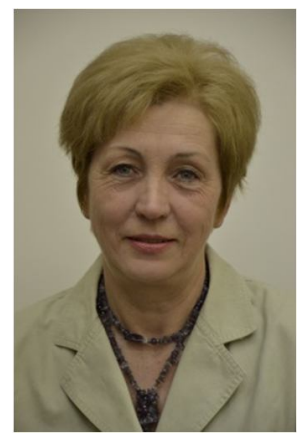

Недбаєвська Людмила Степанівна,

Кандидат педагогічних наук, доцент, доцент кафредри фрізики,

Миколаївський національний університет ім. В.О. Сухомлинського,

вул. Нікольська, 24, м. Миколаїв, 54001

Тел. (0512)37-88-16 . E-mail: docent1812@gmail.com

Nedbaievska Ludmyla Stepanivna,

Candidate of Pedagogical Sciences, Associate Professor, Associate Professor of Department of Physics,

V.O. Sukhomlynskyi Mykolaiv National University

Nikolska Street, 24, Mykolaiv 54001, Ukraine

Tel. (0512)37-88-16 . E-mail: docent1812@gmail.com

ORCID: 0000-0002-7118-6821 


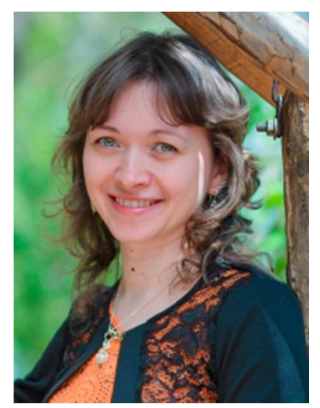

\section{Дармосюк Валентина Миколаївна,}

Кандидат фізико-математичних наук, старший викладач кафедри фізики, Миколаївський національний університет ім. В.О. Сухомлинського,

вул. Нікольська, 24, м. Миколаїв, 54001

Тел. (0512)37-88-16 .E-mail: darmosiuk@gmail.com

\section{Darmosiuk Valentyna Mykolaivna,}

Candidate of physical and mathematical sciences, Senior Lecturer of Department of Physics,

V.O. Sukhomlynskyi Mykolaiv National University

Nikolska Street, 24, Mykolaiv 54001, Ukraine

Tel. (0512)37-88-16 .E-mail: darmosiuk@gmail.com

\section{ORCID: 0000-0003-3275-8249}

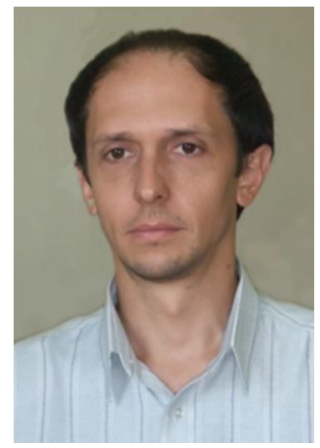

\section{Пархоменко Олександр Юрійович,}

Кандидат фізико-математичних наук, доцент кафедри фізики,

Миколаївський національний університет ім. В.О. Сухомлинського,

вул. Нікольська, 24, м. Миколаїв, 54001.

Тел. (0512)37-88-16. E-mail: alex777par@gmail.com

\section{Parkhomenko Oleksandr Yuriyovich.}

Candidate of Pedagogical Sciences, Associate Professor, Associate Professor of Department of Physics,

V.O. Sukhomlynskyi Mykolaiv National University

Nikolska Street, 24, Mykolaiv 54001, Ukraine

Tel. (0512)37-88-16.E-mail: alex777par@gmail.com

ORCID: 0000-0002-7940-7414

\section{Citation (APA):}

Mankus, I., Nedbaievska, L., Darmosiuk, V., Parkhomenko, O. (2020). Innovative educational environment: technologies of creation. Engineering and Educational Technologies, 8 (1), 85-94. doi: https://doi.org/10.30929/2307-9770.2020.08.01.07

\section{Цитування (ДСТУ 8302:2015):}

Манькусь І. В., Недбаєвська Л. С., Дармосюк В. М., Пархоменко О. Ю. Інноваційне освітне середовище: технології створення / Інженерні та освітні технології. 2020. Т. 8. № 1. С. 85-94. doi: https://doi.org/10.30929/2307-9770.2020.08.01.07

Обсяг статmі: $\quad$ сторінок - 10 ; умовних друк. аркушів - $1,448$. 